\title{
SMALL-MAMMAL REGULATION OF VEGETATION STRUCTURE IN A TEMPERATE SAVANNA
}

\author{
Jake F. Weltzin, ${ }^{1}$ Steve Archer, and Rod K. Heitschmidt ${ }^{2}$ \\ Department of Rangeland Ecology and Management, Texas A\&M University, College Station, Texas 77843-2126
}

\begin{abstract}
Explanations for documented increases in woody plant dominance in grasslands and savannas of North America include atmospheric $\mathrm{CO}_{2}$ enrichment and changes in climate, livestock grazing, and fire regimes. However, tree/shrub encroachment has also coincided with the eradication of a once widespread native herbivore, the black-tailed prairie dog (Cynomys ludovicianus). We used field experiments and repeat aerial photography to demonstrate that prairie dogs, and the herbivores and granivores associated with their colonies, probably maintained grassland and savanna by preventing woody species such as Prosopis glandulosa (honey mesquite) from establishing or attaining dominance.

Prosopis seed and pod disappearance was 3-99 times greater within prairie dog colonies. Ants were the primary agent of seed removal, whereas prairie dogs and associated vertebrates were the primary agents of pod removal. Survival of Prosopis seedlings protected from vertebrate herbivory was similar on and off prairie dog colonies $(\approx 60 \%)$, whereas survival of unprotected seedlings was 3 times greater off- than on-colony. On-colony, prairie dogs and associated herbivores girdled and destroyed all Prosopis saplings within $2 \mathrm{~d}$ of planting; survival of 1-yr-old seedlings was reduced by $50 \%$ after 3 mo of exposure to on-colony herbivores. Despite high levels of woody plant seed disappearance and seedling herbivory, on-colony "seedling" reserves were substantial (950 plants/ha). Thus, prairie dogs and the fauna that occur on their colonies suppressed rather than eliminated Prosopis from the colony site. Removal of prairie dogs led to rapid development of Prosopis stands. Repeat aerial photography showed that Prosopis canopy cover on a colony eradicated in $1950(27 \%)$ increased to a level (61\%) comparable to that of off-colony Prosopis stands $(65 \%)$ within $23 \mathrm{yr}$.

These data illustrate how transitions from grassland to woodland vegetation can be mediated by a rodent herbivore. They further demonstrate how purposeful or inadvertent removal of native herbivores can have unforeseen effects on plant species composition and landscape physiognomy. Investigations of environmental constraints on vegetation distribution and abundance should take into account the historical role of herbivores in shaping the present system. Inconsistencies among historic accounts of woody plant distribution and abundance in semiarid western North America may be resolved by considering population dynamics of prairie dogs. Widespread eradication of this formerly abundant rodent has eliminated a significant constraint to woody plant establishment on many semiarid grassland and savanna landscapes and has thereby facilitated transitions to shrubland and woodland states. Past land management designed to remove one perceived impediment to livestock production appears to have contributed significantly to development of another management problem that is now a major detriment to sustainable livestock production.
\end{abstract}

Key words: competition; Cynomys ludovicianus; herbivory; mesquite; prairie dogs; Prosopis glandulosa; seed disappearance; seedling establishment; succession; tree-grass dynamics.

\section{INTRODUCTION}

Historic increases in woody plant stature and density in savannas and grasslands have been documented worldwide (Archer 1995). These changes in vegetation are of considerable socioeconomic concern, as they often contribute to reductions in livestock carrying capacity and thus impact commercial enterprises, pastoral

Manuscript received 11 January 1996; revised 18 June 1996; accepted 20 June 1996.

${ }^{1}$ Present address: School of Renewable Natural Resources, University of Arizona, Tucson, Arizona 85721 USA.

${ }^{2}$ Present address: USDA/ARS Fort Keogh, Route 1, Box 2021, Miles City, Montana 59301 USA. societies, and subsistence cultures in arid and semiarid environments (Heady 1975, Scifres 1980, Schofield and Bücher 1986, Skarpe 1991, MacLeod 1993, Walker 1993, Young and Solbrig 1993, Bastian et al. 1995). Woody plant encroachment into grasslands and savannas also has potentially important ramifications for desertification, biodiversity, wildlife habitat conservation, nutrient cycling, and soil erosion (Grover and $\mathrm{Mu}-$ sick 1990, Schlesinger et al. 1990, Hibbard 1995). To date, our understanding of the proximate causes for these changes in vegetation and the factors influencing their rates, dynamics, and patterns across landscapes are poorly understood. Mesquite (Prosopis glandulosa 
[honey mesquite] and $P$. velutina [velvet mesquite]) exemplifies this phenomenon in southwestern North America. Although the geographic range of these unpalatable, arborescent legumes has changed little in southwestern North America in the past 300-500 yr (Johnston 1963), their stature and density have increased markedly in grasslands and savannas since Euroamerican settlement (Inglis 1964, Buffington and Herbel 1965, Hennessy et al. 1983, Archer 1989, Turner 1990, Bahre and Shelton 1993).

Considerable speculation exists regarding what factors might have changed over the past century to enable encroachment of Prosopis and other woody species into grasslands. Traditional explanations center around the interactive effects of livestock grazing and reductions in fire frequency or intensity that occurred against a backdrop of periodic drought and directional climate change (Hastings and Turner 1965, Herbel et al. 1972, Neilson 1986, Archer 1994). More recently, it was proposed that increases in atmospheric $\mathrm{CO}_{2}$ concentrations since the industrial revolution have favored woody plants over grasses (Idso 1992, Johnson et al. 1993). Herbivores are known to exert a significant influence on woody plant distribution and abundance in grasslands and savannas of Africa (e.g., Sinclair 1979, Belsky 1984, Yeaton 1988, Dublin et al. 1990, Stuart-Hill 1992), but their potential role in regulating vegetation dynamics has received less consideration in North America. In this paper, we test the hypothesis that the black-tailed prairie dog (Cynomys ludovicianus Ord. [Sciuridae]) is a keystone herbivore (sensu Paine 1966, Brown and Heske 1990, Mills et al. 1993) and ecosystem engineer (Jones et al. 1994) that can maintain grasslands by preventing woody species such as Prosopis from establishing or attaining dominance. We propose that widespread anthropogenic extermination of extensive prairie dog colonies in the early 1900s removed a significant constraint to woody plant establishment, thereby increasing the likelihood of transitions from grassland and savanna to shrubland or woodland.

The geographic range of black-tailed prairie dogs extends from north-central Mexico to southern Canada and from eastern Nebraska to western Montana (Hall 1981). Colonies are selectively located on portions of the landscape with gentle slopes and deep soils that are not flood prone (Dahlsted et al. 1981). The number and extent of prairie dog colonies in western North America prior to Euroamerican settlement is unknown. However, in 1919 , colonies were estimated to occupy $40 \times$ $10^{6}$ ha of the Great Plains and Texas (Nelson 1919), with individual colonies encompassing up to 64750 $\mathrm{km}^{2}$ (Bailey 1905). Prairie dog densities on modern colonies range from 18 to 83 animals/ha and vary with site, season, year, and colony age (Garrett et al. 1982). Vegetation on landscapes inhabited by prairie dogs receives frequent and intense defoliation, and plants not consumed are indiscriminately felled and kept low in stature, presumably to facilitate predator detection (King 1955). In addition, prairie dogs' burrowing activities probably have important indirect effects on vegetation by altering hydrology and nutrient cycling. Prairie dog activities also create habitat for other animals. As a result, the abundance of reptiles, lagomorphs, cricetine rodents, insects, and ants is often higher on prairie dog colonies relative to off-colony (i.e., uncolonized) portions of the landscape (Agnew et al. 1986). Activities of these animals, coupled with those of ungulates (bison, antelope, livestock) that preferentially utilize colonies (Coppock et al. 1983b), may intensify grazing (Cid et al. 1991) and seed predation to further influence plant composition, production, and nutrient cycling (Whicker and Detling 1988).

Prairie dogs have been widely regarded by livestock producers as rangeland pests. Despite evidence to the contrary (e.g., Coppock et al. 1983a, $b$ ) they are generally assumed to compete with domestic livestock for forage, and to create health hazards. Extensive eradication programs in the early 1900s reduced the area of prairie dog colonies in the United States by an estimated 98\% (U.S. Department of Interior 1963). The removal of this widespread, abundant herbivore undoubtedly influenced vegetation patterns, secondary succession, and plant life-form interactions (cf. Chew 1976, Louda 1989, Brown and Heske 1990) and may have contributed to increases in tree and shrub recruitment on southwestern landscapes.

Our goal was to determine the influence of prairie dogs and the fauna associated with their colonies on the relative abundance and dominance of herbaceous and woody vegetation. We targeted mesquite (Prosopis glandulosa var. glandulosa Torr.) because of the widespread ecological and socioeconomic significance of this genus in southwestern North America, South America, Africa, and Australia (Simpson 1977, McArthur 1984, McKell 1989). Specifically, we (1) experimentally quantified $P$. glandulosa seed and pod removal, and seedling emergence and persistence, on prairie dog colonies relative to portions of the landscape not occupied by prairie dogs; (2) inventoried the "seedling" reserve of Prosopis on prairie dog colonies; and (3) quantified temporal changes in Prosopis abundance on a landscape where prairie dogs were eradicated in 1950.

\section{Methods \\ Study sites}

The study was conducted in 1988 and 1989 near the eastern edge of the Rolling Plains resource area (Gould 1975) in north-central Texas. The climate of the region is characterized by hot summers, mild winters, and a 220 -d frost-free period that extends from March to November. Average annual precipitation $(682 \mathrm{~mm})$ is bimodally distributed, with peaks in May $(96 \mathrm{~mm})$ and September $(118 \mathrm{~mm})$. Annual rainfall was $489 \mathrm{~mm}$ in 
1988 and $564 \mathrm{~mm}$ in 1989. Regional physiognomy varies from grassland to Prosopis-dominated savanna and woodland with an herbaceous understory of short- and mid-height grasses. See Heitschmidt et al. (1985) for additional details on soils, climate, and vegetation of the study area. Small mammals in the region include cricetine rodents (e.g., Neotoma micropus, Reithrodontomys spp., Baiomys taylori, Peromyscus spp.) and lagomorphs (e.g., Lepus californicus, Sylvilagus spp.) (Davis and Schmidly 1994).

We studied two colonies of black-tailed prairie dogs on the W. T. Waggoner Estate Ranch in Throckmorton County near Vernon, Texas. Both colonies were at least $50 \mathrm{yr}$ old, and both were situated on clay loam soils (Soil Conservation Service 1959). The Santa Rosa (SR) colony ( $33^{\circ} 48^{\prime} \mathrm{N}, 99^{\circ} 29^{\prime} \mathrm{W}$; elevation $369 \mathrm{~m}$ ) occupied 15 ha of nearly level terrain within a 2000-ha Stipa leucotricha-Buchloe dactyloides grassland. The area had been grazed at moderate stocking density by cattle from October to May. The North Fork (NF) colony $\left(33^{\circ} 57^{\prime} \mathrm{N}, 99^{\circ} 19^{\prime} \mathrm{W}\right.$; elevation $\left.405 \mathrm{~m}\right)$, occupied $\approx 6$ ha. The colony was situated within a $S$. leucotricha-B. dactyloides-P. glandulosa-Ziziphus obtusifolia savanna. The pasture that contained the NF colony had been grazed continuously by cattle at a moderate stocking density since the mid-1900s.

Prairie dog colonies are often characterized by distinct concentric zones of vegetation, the composition of which varies as a function of habitation history (Archer et al. 1987, Whicker and Detling 1988). Three vegetation zones were apparent at each colony. The interior zone had abundant burrow mounds interspersed in a matrix of short-statured $(2-15 \mathrm{~cm})$ graminoids and scattered herbs. The off-colony zone lacked burrows and was dominated by mid-statured $(>25 \mathrm{~cm})$ graminoids. Transitions between the on-colony and off-colony zones were characterized by occasional burrows and a mixture of short- and mid-statured graminoids. Prosopis plants of seed-producing stature were absent on both colonies.

Cattle were excluded from a 2-ha portion of the SR site with a permanent three-strand barbed-wire fence that extended into the off-colony vegetation. All seedling establishment trials were conducted within this exclosure. No livestock exclosure was constructed at the NF site.

\section{Prosopis seed and pod disappearance}

Prosopis seed production typically occurs in July and August. Seeds are typically $5 \mathrm{~mm}$ wide, $7 \mathrm{~mm}$ long, and $\approx 0.05 \mathrm{~g}$ in mass. Ripened seeds are long lived ( $\geq 40 \mathrm{yr}$; Tschirley and Martin 1960) and have hard coats that require scarification before germination will occur. Seeds are borne in a fleshy carpel (pod) that is widely consumed by wildlife and domestic livestock; many of the ingested seeds escape mastication and are germinable after excretion (see Brown and Archer 1987). Seeds produced off-colony may therefore be readily dispersed onto colonies by wildlife or livestock. Previous research suggests that utilization of Prosopis pods and seeds by birds is minimal (El Youssoufi 1992). We quantified daily removal of seeds and pods from 7-10 plots randomly located in on- and off-colony zones at SR in August 1988 and at both colonies in July and August 1989. Within each plot, we established three cafeteria-style feeding stations, each with two petri dishes. One petri dish was made inaccessible to ants (Pogonomyrmex spp.) (AI) by elevating it $6 \mathrm{~cm}$ on an inverted glass jar that allowed vertebrate access. The second petri dish was placed at ground level and was accessible to ants (AA) and vertebrates. Each pair of dishes was randomly assigned to one of three vertebrate exclosure treatments: all (A), partial (P), or none $(\mathrm{N})$. Exclosures constructed of 1-cm mesh hardware cloth $(23 \mathrm{~cm}$ long $\times 23 \mathrm{~cm}$ wide $\times 25 \mathrm{~cm}$ high with closed tops) excluded all ("A") vertebrates (e.g., prairie dogs, lagomorphs, and small rodents). Semipermeable or partial ("P") vertebrate exclosures were constructed from $2.5-\mathrm{cm}$ hexagonal wire netting (25 $\mathrm{cm}$ diameter, $36 \mathrm{~cm}$ tall, with closed tops) that allowed cricetine rodents access to stations but excluded larger prairie dogs and lagomorphs. Prosopis seeds and pods at the third station were not exclosed ("N"), and were fully accessible to all vertebrates.

We conducted field trials with either all seeds or all pods. For each trial, we placed five pod segments (8$12 \mathrm{~mm}$ long; $\approx 0.25 \mathrm{~g}$ air dry mass) or five seeds $(\approx 0.05$ $\mathrm{g}$ each) into each of the petri dishes, and recorded the number removed from each dish after $24 \mathrm{~h}$. Dishes were then replenished with fresh seeds or pods as necessary; seeds were replaced with pods, or vice versa, for the next trial. Trials were 1-5 d in duration, depending upon weather constraints on site accessibility, and were conducted on different dates at the two colonies. Seed and pod removal were quantified for a total of 8 trials at $\mathrm{SR}$ in 1988 , and a total of 16 trials at SR and 11 trials at NF in 1989.

\section{Herbaceous standing crop}

Herbaceous standing crop was quantified in July 1988 and August 1989 at SR to document differences in grass and forb composition resulting from prairie dog habitation. Aboveground biomass was harvested by species from circular $0.25-\mathrm{m}^{2}$ plots randomly located within on-colony, transition, and off-colony zones $(n=20$ plots/zone in 1988; $n=10$ plots/zone in 1989). Biomass was oven-dried at $60^{\circ} \mathrm{C}$ to constant mass, and weighed to the nearest $0.1 \mathrm{~g}$.

\section{Seedling establishment}

Prosopis seedling establishment was quantified at the SR colony. In 1988 and 1989, 60 plots $(2 \times 2$ m) were randomly located within each of three vegetation zones (on-colony, transition, off-colony). Each plot was randomly assigned to one of three vegetation interference treatments: no interference (NI), simulated grazing of 
herbaceous plants (SG), and full interference (FI). The NI treatment was designed to minimize herbaceous interference (e.g., shading, competition for water or nutrients) with Prosopis establishment and growth and to increase Prosopis seedling apparency to herbivores. This was achieved through application of a nonspecific contact herbicide (Roundup) followed by post-treatment removal of standing crop $1 \mathrm{wk}$ prior to initiation of the experiment. The NI treatment was maintained by hand weeding. The SG treatment was designed to simulate grazing of herbaceous vegetation and was achieved by clipping vegetation within plots to a $3-\mathrm{cm}$ height at monthly intervals. The third treatment was an indigenous control with full interference.

Our primary objective in this phase of the study was to quantify the seedling establishment phase of the Prosopis life cycle. We therefore used scarified seed (laboratory germination $=90 \%$ ) collected from populations near College Station, Texas. Prosopis seeds readily germinate when placed on the soil surface (Brown and Archer 1989) or when planted at depths of up to 2-4 cm (Haas et al. 1973, Simpson 1977). To minimize predation losses and variability associated with soilseed contact effects on germination, we planted seeds at a depth of $0.5 \mathrm{~cm}$ on 27 June 1988 and 30 May 1989. Within each plot, three groups of 20 seeds each were randomly assigned to the $\mathrm{A}, \mathrm{P}$, and $\mathrm{N}$ exclosure treatments. To facilitate germination and emergence, plots were watered at 2-d intervals until the first true leaves emerged $(\approx 1$ wk after planting). The proportion of seeds germinating was recorded $7 \mathrm{~d}$ after planting (1988 only). Seedlings were then thinned to three per exclosure treatment. Seedling survival was recorded monthly through August, and again in November.

\section{Fate of established and transplanted Prosopis plants}

To assess the impact of prairie dogs and associated herbivores on established Prosopis seedlings, we randomly removed $\mathrm{A}$ and $\mathrm{P}$ exclosures protecting 48 seedlings that had emerged in 1988. Exclosures were removed on 17 May 1989; 15 on-colony seedlings under $\mathrm{A}$ and $\mathrm{P}$ exclosures were maintained as controls. Plant survival and height were monitored through August 1989.

To assess the impact of prairie dogs on larger Prosopis plants, we transplanted foliated branches of Prosopis into on-colony, transition, and off-colony zones at SR and NF to simulate Prosopis "saplings." Transplanting consisted of inserting basal ends of foliated Prosopis branches 5-10 cm into the soil. In July 1988, four transects with 20 "saplings" each (stem diameter $=5-6 \mathrm{~mm}$; mean height $[ \pm 1 \mathrm{sE}]=27 \pm 1 \mathrm{~cm}$ ) were established in each zone at NF. Saplings were monitored daily for $38 \mathrm{~d}$ and replaced as they withered. Length of shoot $(\mathrm{cm})$ protruding from the soil, linear length $(\mathrm{cm})$ of bark removed, and girdling or severing of stems were noted on daily visits. In 1989, the experiment was repeated and included the SR colony and larger saplings (stem diameter $=12-20 \mathrm{~mm}$; height $=$ $76 \pm 3 \mathrm{~cm}$ ). The 1989 transplant experiment was conducted for three trials of three consecutive days in June, and one trial in August ( $n=480$ and 240 small and large saplings, respectively).

\section{Occurrence of Prosopis on prairie dog colonies}

We determined density, cover, and height of Prosopis in 10 belt transects $(2 \times 50 \mathrm{~m})$ on and off each colony in 1989. Individual plants were classified as seedlings when cotyledons were present or saplings when cotyledons had dehisced and stems were lignified.

\section{Stand development after prairie dog removal}

Throckmorton County records indicated that a colony of prairie dogs in Rock Canyon $\left(33^{\circ} 25^{\prime} \mathrm{N}, 99^{\circ} 11^{\prime}\right.$ W; 406 m elevation) was eradicated in December 1950. Aerial photographs that portrayed the colony site were obtained for 1950, 1963, and 1973. Positive transparencies of these photographs were spatially registered to a common scale $(1: 2500)$ with a Kronz reflecting projector. Changes in canopy cover (as a percentage) of Prosopis on the area occupied by prairie dogs were quantified by tracing canopies onto frosted acetate and digitizing the resulting polygons into a geographic information system. Off-colony canopy cover was similarly estimated within two spatially registered circular plots (2.41 ha each).

In 1990, we quantified the structure of Prosopis stands on and off the former Rock Canyon colony. Belt transects $(2 \times 60 \mathrm{~m})$ were randomly located within stands with similar soils on $(n=10)$ and off $(n=5)$ the former colony site. Plant density, plant basal area, total basal area, and relative canopy cover was determined. Prosopis size/age relationships were determined from basal stem cross-sections obtained from six trees on and off the former Rock Canyon colony site. The cross sections, which ranged from 7 to $34 \mathrm{~cm}$ in diameter, were sanded, stained, and aged by ring counts as described by Flinn et al. (1994).

\section{Statistical analysis}

First- and second-order interactions were included in ANOVA models. General linear model procedures were used for unbalanced designs (SAS Institute 1988). Results were considered significant at $P<0.05$. To simplify interpretation, second-order interactions with Type III sums of squares that contributed $<2 \%$ to the model sum of squares were combined with the error term, and the model reanalyzed. Tukey's hsd multiplemeans comparison test was used to compare levels within factors for all significant $(P<0.05)$ main effects and first-order interactions. We performed arcsine transformations (Steel and Torrie 1980) on proportional data, and square-root transformations on all other data. Mean separation tests were conducted on transformed data when necessary. Nontransformed, least-squares means are presented in the tables and figures. When 
TABLE 1. Mean ( $\pm 1 \mathrm{SE}$ ) peak herbaceous standing crop ( $\mathrm{kg} / \mathrm{ha}$ ), by functional group, at the Santa Rosa colony for on-colony, transition, and off-colony zones in 1988 and 1989.

\begin{tabular}{lcccr}
\hline \hline & & \multicolumn{3}{c}{ Zone } \\
\cline { 3 - 5 } Functional group & Year & On-colony & Transition & Off-colony \\
\hline Mid-grasses & 1988 & $123 \pm 31$ & $894 \pm 207$ & $745 \pm 137$ \\
& 1989 & $29 \pm 29$ & $\cdots$ & $2059 \pm 350$ \\
Short grasses & 1988 & $616 \pm 67$ & $731 \pm 143$ & $778 \pm 162$ \\
\multirow{2}{*}{ Annual grasses } & 1989 & $839 \pm 178$ & $\ldots$ & $568 \pm 247$ \\
& 1988 & $0 \pm 0$ & $35 \pm 20$ & $430 \pm 73$ \\
Forbs & 1989 & $0 \pm 0$ & $\ldots$ & $431 \pm 185$ \\
Total & 1988 & $33 \pm 12$ & $38 \pm 18$ & $70 \pm 42$ \\
& 1989 & $133 \pm 75$ & $\ldots$ & $337 \pm 143$ \\
& 1988 & $771 \pm 71$ & $1698 \pm 130$ & $2022 \pm 144$ \\
& 1989 & $1001 \pm 215$ & $\cdots$ & $3394 \pm 265$ \\
\hline
\end{tabular}

means from $\mathrm{A}$ and $\mathrm{P}$ exclosure treatments were not different, data were pooled and the model reanalyzed.

Seed and pod removal data for 1988 and 1989 were analyzed separately. Data from ant-inaccessible (AI) stations in 1988 were excluded from consideration because of design problems with the seed trays. This problem was rectified for the 1989 trials. We used a nested-factorial ANOVA design (Hicks 1973, Smith and Beverly 1981) to analyze proportional seed and pod removal data. Colony, zone, exclosure, and ant access represented crossed factors; trial was nested within colony because trials were conducted on different dates at each colony. For the seedling establishment experiment, mean end-of-season seedling survival for 1988 and 1989 was analyzed in a crossed (year, zone, vegetation treatment, exclosure) ANOVA model. Effects of prairie dogs on the survival and height of established Prosopis seedlings were analyzed with Studentized $t$ tests. Manipulation of simulated Prosopis saplings was analyzed with separate crossed (month, colony, zone) and nested (trial within month) ANOVA models for differences in stem cutting height, number of secondary branches clipped, length of stem bark stripped, and proportion of stems girdled. Density, cover, and height of Prosopis on and off each colony were analyzed with a crossed (colony, zone) ANOVA model. Plant density, plant basal area, total basal area, and relative canopy cover on and off the former Rock Canyon colony were analyzed with a nested (transect within zone) ANOVA model for differences between zones. Plant densities within a basal area class on and off the former colony were rank-transformed prior to analysis of variance (Conover and Iman 1981). Simple linear regression was used to assess basal diameter-age relationships of Prosopis stems on and off the former Rock Canyon colony site.

\section{RESUlts}

\section{Herbaceous standing crop}

Total herbaceous standing crop within the livestock exclosure at $\mathrm{SR}$ was $\approx 3$ times greater off-colony than on-colony (Table 1; J. F. Weltzin, S. L. Dowhower, and R. K. Heitschmidt, unpublished manuscript). No an- nual grasses occurred on-colony in either year, and short-grass biomass was comparable between zones and years. Mid-grass biomass (primarily Stipa leucotricha) was at least 6 times greater off-colony than on-colony; this difference was most pronounced in 1989.

\section{Seed and pod removal}

Patterns of Prosopis seed and pod disappearance differed between on- and off-colony zones (Tables 2 and 3 ). In both years and on both colonies, seed and pod removal rates were comparable for $\mathrm{A}$ and $\mathrm{P}$ exclosures (which were pooled for all subsequent analyses). The cause of removal of a small proportion of seeds and pods from AI stations within rodent-exclosed plots was unknown.

Ant access explained the majority of the variation in the seed removal model (Table 2). Ant access substantially increased seed removal rates at both colonies (Table 3), with the magnitude of ant effects being significantly $(P<0.05)$ influenced by vertebrate accessibility and zone. For example, when vertebrates had access to seeds, ant access increased removal rates by $60 \%(P<0.05)$; when vertebrates were excluded, ant access increased seed removal sevenfold. Seed removal rates were significantly greater on- than off-colony, with differences between zones being greater for antaccessible (AA) trays (fourfold) than for AI trays (threefold). Seed removal differed significantly between vertebrate exclosure treatments, but was dependent upon zone and colony. On-colony seed removal rates nearly doubled with vertebrate access, whereas off-colony removal rates were not significantly affected by vertebrates $(P>0.05)$. Seed removal from vertebrate-inaccessible trays did not differ significantly between the SR and NF colonies, but was greater at SR than NF when vertebrates had access. Consistent with this pattern, seed removal did not differ significantly for off-colony locations at SR and NF; however, seed removal on the SR colony significantly exceeded that observed at the NF colony. Patterns of seed removal were similar between the two years for the SR colony.

Pod removal attributed to prairie dogs and associated 
TAble 2. ANOVA summary of Prosopis pod and seed removal for effects of colony (Santa Rosa or North Fork), zone (oncolony, off-colony), rodent exclosure type (pooled A [all] and P [partial] exclosures and $\mathrm{N}$ [no exclosure]), and ant accessibility.

\begin{tabular}{|c|c|c|c|c|c|c|c|c|c|c|}
\hline \multirow[b]{2}{*}{ Source } & \multicolumn{5}{|c|}{ Pod removal } & \multicolumn{5}{|c|}{ Seed removal } \\
\hline & $\mathrm{df}$ & MS & $F$ & $P$ & $r^{2}$ & $\mathrm{df}$ & MS & $F$ & $P$ & $r^{2}$ \\
\hline Colony & 1 & 2.189 & 34.44 & 0.0001 & 5.2 & 1 & 0.185 & 1.17 & 0.2905 & 0.6 \\
\hline Trial (Colony) & 25 & 0.063 & 6.36 & 0.0001 & 3.8 & 25 & 0.159 & 7.21 & 0.0001 & 12.6 \\
\hline Zone & 1 & 5.207 & 243.25 & 0.0001 & 12.4 & 1 & 4.36 & 51.37 & 0.0001 & 13.8 \\
\hline Colony $\times$ Zone & 1 & 0.257 & 12.00 & 0.0019 & 0.6 & 1 & 0.593 & 6.99 & 0.0139 & 1.9 \\
\hline Trial $\times$ Zone (Colony) & 25 & 0.021 & 2.14 & 0.0026 & 1.3 & 25 & 0.085 & 3.86 & 0.0001 & 6.7 \\
\hline Exclosure & 2 & 7.951 & 434.64 & 0.0001 & 37.9 & 2 & 0.875 & 42.25 & 0.0001 & 5.6 \\
\hline Colony $\times$ Exclosure & 2 & 0.10 & 0.54 & 0.5816 & $<0.1$ & 2 & 0.083 & 3.99 & 0.0215 & 0.5 \\
\hline Zone $\times$ Exclosure & 2 & 4.479 & 244.84 & 0.0001 & 21.3 & 2 & 0.411 & 19.87 & 0.0001 & 2.6 \\
\hline Colony $\times$ Trial $\times$ Zone $\times$ Exclosure & 101 & 0.018 & 1.83 & 0.0003 & 4.4 & 102 & 0.021 & 0.94 & 0.6275 & 6.7 \\
\hline Ant access & 1 & 1.674 & 167.60 & 0.0001 & 4.0 & 1 & 9.115 & 414.13 & 0.0001 & 28.9 \\
\hline Colony $\times$ Ant $A$ & 1 & 0.774 & 77.51 & 0.0001 & 1.8 & 1 & 0.008 & 0.36 & 0.5481 & $<0.1$ \\
\hline Zone $\times$ Ant access & 1 & 0.0001 & 0.01 & 0.9071 & $<0.1$ & 1 & 0.966 & 43.86 & 0.0001 & 3.1 \\
\hline Exclosure $\times$ Ant access & 2 & 0.166 & 16.64 & 0.0001 & 0.7 & 2 & 0.248 & 11.28 & 0.0001 & 1.6 \\
\hline Error & 156 & 0.01 & & & & 156 & 0.022 & & & \\
\hline
\end{tabular}

Note: Three-way interactions between colony, zone, exclosure, and access terms each contributed $<2 \%$ to model sums of squares, and are included with the error term. Means are presented in Table 3. Model $R^{2} \mathrm{~s}$ for pod and seed removal were 0.96 and 0.89 , respectively.

vertebrates too large to access both $\mathrm{P}$ and $\mathrm{A}$ exclosures (e.g., lagomorphs) typically exceeded the level of seed removal. Several times we observed prairie dogs remove pods, consume the fleshy carpel, and then discard the seed intact. Exclosure and the zone $\mathrm{x}$ exclosure interaction explained the most variation in the pod removal model (Table 2). Most pods (96-99\%) were removed from on-colony stations accessible to vertebrates (Table 3). Pod removal from vertebrate-accessible stations was on average 4 times greater on than off-colony, but did not differ between zones when vertebrates could not access pods $(P>0.05)$. Differences in pod removal by vertebrates were also colony-dependent: pod removal was 11 times greater on- than off-colony at NF, and $\approx 2$ times greater at SR $(P<$ 0.05).

Pod removal was greater from AA than AI trays, which suggests that ants removed some pods. However, differences were dependent on colony and vertebrate access. Pod removal from AI and AA trays was 50 and $100 \%$ greater at SR than at NF $(P<0.05)$. Ant access increased pod removal sevenfold when vertebrates were excluded, but only $\approx 10 \%(P<0.05)$ when vertebrates had access. Vertebrate access increased pod removal 3-19-fold for AI and AA trays, respectively, but pod removal did not differ between the two tray types $(P>0.05)$. Differences in pod removal were also year dependent: pod removal rates at the SR site in 1988 were approximately half those observed in 1989.

\section{Seedling establishment}

Prosopis seedling emergence was statistically comparable between vegetation treatments and for A and $\mathrm{P}$ exclosures (data not shown). Seedling emergence was greater $(P<0.05)$ inside than outside exclosures oncolony, but not in the transition and off-colony zones (Table 4). Overall emergence was greatest $(P<0.05)$ in the transition zone. End-of-season survival of Prosopis seedlings did not differ between main effects of year, zone, or vegetation treatment, or between A and P exclosures (Table 5). Establishment of Prosopis seedlings protected from vertebrates was uniformly high

TABLE 3. Mean ( \pm 1 SE) seed and pod removal (\%) for 1988 and 1989, from ant-accessible and ant-inaccessible stations with and without vertebrate exclosures on and off the Santa Rosa (SR) and North Fork (NF) prairie dog colonies.

\begin{tabular}{|c|c|c|c|c|c|c|c|c|c|}
\hline \multirow[b]{3}{*}{ Year } & \multirow[b]{3}{*}{ Colony } & \multicolumn{4}{|c|}{ Ant-accessible } & \multicolumn{4}{|c|}{ Ant-inaccessible } \\
\hline & & \multicolumn{2}{|c|}{ Exclosed } & \multicolumn{2}{|c|}{ No exclosure } & \multicolumn{2}{|c|}{ Exclosed } & \multicolumn{2}{|c|}{ No exclosure } \\
\hline & & On & Off & On & Off & On & Off & On & Off \\
\hline \multicolumn{10}{|l|}{ Seeds } \\
\hline 1988 & SR & $88 \pm 6$ & $31 \pm 6$ & $86 \pm 6$ & $36 \pm 6$ & $\ldots$ & $\ldots$ & $\ldots$ & $\ldots$ \\
\hline 1989 & SR & $67 \pm 5$ & $27 \pm 5$ & $85 \pm 5$ & $32 \pm 5$ & $9 \pm 5$ & $2 \pm 5$ & $59 \pm 5$ & $13 \pm 5$ \\
\hline & $\mathrm{NF}$ & $54 \pm 6$ & $33 \pm 6$ & $63 \pm 6$ & $34 \pm 6$ & $6 \pm 6$ & $7 \pm 6$ & $40 \pm 6$ & $13 \pm 6$ \\
\hline \multicolumn{10}{|l|}{ Pods } \\
\hline 1988 & SR & $20 \pm 7$ & $17 \pm 7$ & $50 \pm 7$ & $26 \pm 7$ & $\ldots$ & $\ldots$ & $\ldots$ & $\ldots$ \\
\hline 1989 & SR & $39 \pm 3$ & $31 \pm 3$ & $98 \pm 3$ & $51 \pm 3$ & $2 \pm 3$ & $5 \pm 3$ & $96 \pm 3$ & $31 \pm 3$ \\
\hline & $\mathrm{NF}$ & $6 \pm 4$ & $7 \pm 4$ & $99 \pm 4$ & $4 \pm 4$ & $0 \pm 4$ & $0 \pm 4$ & $99 \pm 4$ & $1 \pm 4$ \\
\hline
\end{tabular}


TABLE 4. Mean emergence (\%) in 1988 of exclosed and nonexclosed Prosopis seedlings on the Santa Rosa prairie dog colony, in the transition zone, and off the colony.

\begin{tabular}{cccc}
\hline \hline & \multicolumn{3}{c}{ Zone } \\
\cline { 2 - 4 } Exclosure & On & Transition & Off \\
\hline Yes & $52^{\mathrm{Aa}}$ & $64^{\mathrm{Ba}}$ & $48^{\mathrm{Aa}}$ \\
No & $38^{\mathrm{Ab}}$ & $62^{\mathrm{Ba}}$ & $54^{\mathrm{Ca}}$ \\
\hline
\end{tabular}

Note: Means within a column with the same lowercase superscript letter and means within a row with the same uppercase superscript letter were not significantly different $(P$ $>0.05)$.

$(>75 \%)$ and did not differ between zones (Fig. 1). In contrast, survival of nonprotected seedlings was uniformly low on and at the edge of the colony, but was $\approx 3$ times greater off-colony. While seedling survival within a particular zone was not affected by herbaceous interference (e.g., shading, competition for water or nutrients), experimental reductions in herbaceous interference increased the survival of seedlings protected from rodents, but decreased the survival of unprotected seedlings (Fig. 2).

\section{Fate of established Prosopis seedlings}

Mean height ( \pm 1 SE) of 1-yr-old Prosopis plants was $8.4 \pm 0.9 \mathrm{~cm}$ when vertebrate exclosures were removed from on-colony plots on 17 May. Within 10 $\mathrm{d}$ of exclosure removal, plant survival was $95 \%$, and surviving plants were $6.9 \pm 1.0 \mathrm{~cm}$ tall. On 15 August, plant survival was $51 \%$, and live seedlings were $3.6 \pm$ $1.0 \mathrm{~cm}$ tall. Over the same time period, survival of control plants under rodent exclosures was $100 \%$, and mean height increased from $8.4 \pm 0.9 \mathrm{~cm}$ to $16.2 \pm$ $1.5 \mathrm{~cm}$.

\section{Fate of Prosopis "saplings"}

In 1988, Prosopis branches were used to simulate "saplings." The experimental saplings placed off-colony at NF were not damaged. In contrast, $80 \%$ of the saplings placed on-colony were severed at ground level

TABle 5. ANOVA summary of Prosopis seedling survival (Figs. 1 and 2) for zone (on-colony, transition, off-colony), vegetation treatment (full interference, simulated grazing, no interference), and rodent exclosure type (pooled A [all] and $\mathrm{P}$ [partial] exclosures, and $\mathrm{N}$ [no exclosure]).

\begin{tabular}{lrcrl}
\hline \hline \multicolumn{1}{c}{ Source } & df & MS & \multicolumn{1}{c}{$F$} & $\operatorname{Pr}>F$ \\
\hline Zone & 2 & 0.034 & 1.04 & 0.43 \\
Vegetation treatment & 2 & 0.007 & 0.21 & 0.82 \\
Zone $\times$ Vegetation treatment & 4 & 0.033 & 3.02 & 0.04 \\
Exclosure & 1 & 2.887 & 263.97 & 0.0001 \\
Zone $\times$ Exclosure & 2 & 0.082 & 7.49 & 0.0035 \\
Vegetation treatment $\times$ & 2 & 0.14 & 12.75 & 0.0002 \\
$\quad$ Exclosure & 21 & 0.001 & & \\
Error & & & & \\
\hline
\end{tabular}

Note: The main effect of year and its interactions and the interaction among zone, vegetation treatment, and exclosure contributed $<2 \%$ to model sums of squares, so were included with the error term.

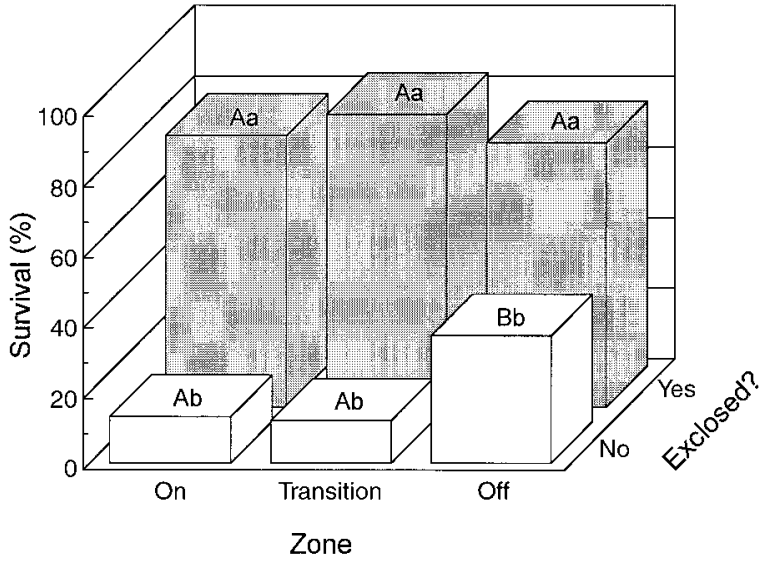

FIG. 1. Mean survival of exclosed Prosopis seedlings and seedlings that were not exclosed, within on-colony, off-colony, and transition zones of the SR prairie dog colony. Means within exclosure with the same uppercase letter and means within zone with the same lowercase letter were not significantly different $(P>0.05)$.

within $1 \mathrm{~d}$; all saplings were felled within $2 \mathrm{~d}$. Among saplings situated at the colony edge, $55 \%$ were felled within $1 \mathrm{~d}$, and $91 \%$ were felled within $38 \mathrm{~d}$.

Main and interactive effects of colony and season were not significant in $1989(P>0.05)$. More small and large saplings were damaged (cut or girdled stems and branches) in the on-colony zone than in transition or off-colony zones (Table 6). Stems were typically severed 10-13 $\mathrm{cm}$ above ground level. Prairie dogs and associated fauna did not cut main stems of larger saplings (12-20 cm diameter), but they severed lower secondary stems, and often stripped enough bark from the lower $30-40 \mathrm{~cm}$ of the primary stem to effectively girdle it.

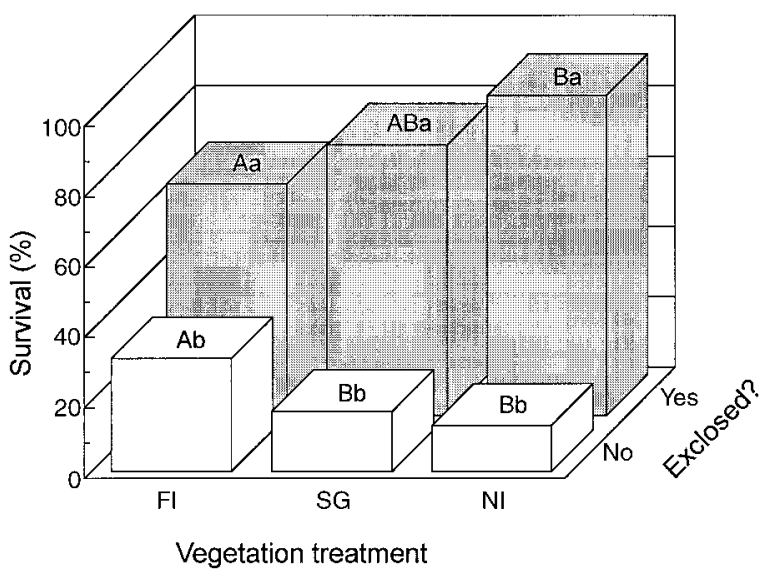

FIG. 2. Mean survival of exclosed Prosopis seedlings and seedlings that were not exclosed in plots with full herbaceous interference (FI), simulated grazing (SG), and no herbaceous interference (NI). Means within exclosure with the same uppercase letter and means within vegetation treatment with the same lowercase letter were not significantly different $(P>$ $0.05)$ 
TABle 6. Fate of transplanted Prosopis "saplings" by zone (on-colony, transition, off-colony) in 1989.

\begin{tabular}{|c|c|c|c|c|}
\hline \multirow{2}{*}{$\begin{array}{l}\text { Sapling } \\
\text { size } \\
\text { class }\end{array}$} & \multirow[b]{2}{*}{ Parameter } & \multicolumn{3}{|c|}{ Zone } \\
\hline & & On & Trans. & Off \\
\hline \multirow[t]{2}{*}{ Small } & Manipulated & $91^{\mathrm{a}}$ & $67^{\mathrm{b}}$ & $0^{c}$ \\
\hline & Height & $10^{\mathrm{a}}$ & $13^{\mathrm{b}}$ & $27^{c}$ \\
\hline \multirow[t]{5}{*}{ Large } & Manipulated & $98^{\mathrm{a}}$ & $58^{\mathrm{b}}$ & $0^{\mathrm{c}}$ \\
\hline & Height & $76^{\mathrm{a}}$ & $76^{\mathrm{a}}$ & $76^{\mathrm{a}}$ \\
\hline & Branches severed & $6^{\mathrm{a}}$ & $3^{\mathrm{b}}$ & $0^{c}$ \\
\hline & Stripped & $36^{a}$ & $10^{\mathrm{b}}$ & $0^{\mathrm{c}}$ \\
\hline & Girdled & $31^{\mathrm{a}}$ & $1^{\mathrm{b}}$ & $0^{\mathrm{b}}$ \\
\hline
\end{tabular}

Note: Effects of colony (Santa Rosa or North Fork) and trial within month (July, August) were not significant $(P>$ $0.05)$, so data were pooled. Data for small saplings are mean percentage manipulated (i.e., bark stripped, branches severed, stem girdled) and residual height $(\mathrm{cm})$. Data for large saplings are mean percentage manipulated, residual height $(\mathrm{cm})$, number of secondary branches severed, linear length $(\mathrm{cm})$ of bark stripped, and percentage of stems girdled. Within rows, means with the same superscript letter were not significantly different $(P>0.05)$.

\section{Occurrence of Prosopis on prairie dog colonies}

Interactive effects of colony and zone were significant $(P<0.05)$ for density, cover, and height of naturally occurring Prosopis seedlings and saplings on and off the SR and NF colonies (Table 7). At NF, seedling and sapling densities were significantly greater on- than off-colony, but saplings off the colony were taller and had greater canopy cover. At SR, sapling density, cover, and height values were comparable between on- and off-colony zones. We encountered no seedlings offcolony at either site.

\section{Stand development after prairie dog removal}

Prosopis canopy cover on and off the Rock Canyon prairie dog colony was 27 and $46 \%$, respectively, when the prairie dogs were eradicated in 1950 (Table 8). By 1973 , canopy cover on the former colony site had increased to a level (61\%) comparable to that of offcolony zones $(65 \%)$. In 1990, canopy cover was greater on than off the former colony site (Table 9). Although the total basal area was comparable on and off the former colony, Prosopis plants on the former colony site were smaller and occurred at a higher density than those off-colony (Tables 9 and 10). Slope and intercept of regressions for basal diameter vs. stem age for onand off-colony zones did not differ $(P>0.05)$ and yielded the following composite relationship:

$$
\mathrm{SA}=19.7+1.256(\mathrm{BD})
$$

where SA is main stem age (in years) and BD is basal diameter (in centimeters) at $20 \mathrm{~cm}$ above ground level ( $\left.n=12 ; P<0.0001 ; R^{2}=0.88\right)$. Based on Eq. 1 , the median age of Prosopis stems was $27 \mathrm{yr}$ (maximum = $81 \mathrm{yr}$ ) and $42 \mathrm{yr}$ (maximum $=76 \mathrm{yr}$ ) on and off the former colony, respectively (Table 9). Eighty-eight percent of the plant stems on the former colony became established after prairie dogs were eradicated in 1950. Among off-colony stands, only $45 \%$ of the Prosopis stems present in the 1990 survey had become established since 1950.

\section{Discussion}

Prairie dogs are known to alter the composition of herbaceous vegetation across landscapes, their influence changing as a function of habitation history (Archer et al. 1987; Whicker and Detling 1988). Our data indicate that prairie dogs and the herbivores associated with their colonies would have been important in creating (e.g., Osborn 1942) or maintaining grasslands or savannas and preventing transitions to alternate shrubland or woodland steady states (cf. Archer 1989, Westoby et al. 1989, Dublin et al. 1990). Their control over ecosystem structure was achieved through a combination of woody plant seed removal and seedling predation and growth suppression.

\section{Prosopis seed removal and seedling establishment}

Defoliation of Prosopis seedlings and removal of seeds and pods attributable to cricetine rodents was minimal on and off prairie dog colonies. In contrast, prairie dogs and associated populations of lagomorphs and ants significantly influenced Prosopis population dynamics by utilizing seeds and pods (Table 3 ) and by cutting or girdling stems of seedling (Figs. 1,2) and juvenile (Table 6) plants.

Ants were the most important agents of Prosopis seed disappearance, and their activities increased by a factor of four on the prairie dog colony. Prairie dogs and/or lagomorphs associated with prairie dog colonies

TABLE 7. Mean density, relative canopy cover, and height of Prosopis saplings (cotyledons dehisced and bark lignified) and seedlings (cotyledons present) on and off the Santa Rosa (SR) and North Fork (NF) colonies in 1989.

\begin{tabular}{|c|c|c|c|c|c|c|c|}
\hline \multirow[b]{2}{*}{ Colony } & \multirow[b]{2}{*}{ Zone } & \multicolumn{3}{|c|}{ Saplings } & \multicolumn{3}{|c|}{ Seedlings } \\
\hline & & $\begin{array}{l}\text { Density } \\
\text { (no./ha) }\end{array}$ & $\begin{array}{c}\text { Cover } \\
(\%)\end{array}$ & $\begin{array}{l}\text { Height } \\
\text { (m) }\end{array}$ & $\begin{array}{l}\text { Density } \\
\text { (no./ha) }\end{array}$ & $\begin{array}{c}\text { Cover } \\
(\%)\end{array}$ & $\begin{array}{l}\text { Height } \\
\text { (m) }\end{array}$ \\
\hline \multirow{2}{*}{ SR } & On & $40^{\mathrm{a}}$ & $<1^{\mathrm{a}}$ & $0.06^{\mathrm{a}}$ & $0^{\mathrm{a}}$ & $0^{\mathrm{a}}$ & $0^{\mathrm{a}}$ \\
\hline & Off & $60^{\mathrm{ac}}$ & $<1^{\mathrm{a}}$ & $0.13^{\mathrm{a}}$ & $0^{\mathrm{a}}$ & $0^{\mathrm{a}}$ & $0^{\mathrm{a}}$ \\
\hline \multirow[t]{2}{*}{ NF } & On & $580^{\mathrm{b}}$ & $<1^{\mathrm{a}}$ & $0.06^{\mathrm{a}}$ & $370^{\mathrm{b}}$ & $<1^{\mathrm{b}}$ & $0.02^{\mathrm{b}}$ \\
\hline & Off & $250^{\mathrm{c}}$ & $6^{b}$ & $1.26^{\mathrm{b}}$ & $0^{\mathrm{a}}$ & $0^{\mathrm{a}}$ & $0^{\mathrm{a}}$ \\
\hline
\end{tabular}

Note: Within a column, means with the same superscript letter were not significantly different $(P>0.05)$. 
TABle 8. Total Prosopis canopy cover (\%) on and off the former Rock Canyon prairie dog colony, as determined from aerial photographs. Prairie dogs were eradicated from the colony in 1950 .

\begin{tabular}{lccc}
\hline \hline & \multicolumn{3}{c}{ Year } \\
\cline { 2 - 4 } \multicolumn{1}{c}{ Zone } & 1950 & 1963 & 1973 \\
\hline Former colony & 27 & 35 & 61 \\
Off-colony & 46 & 42 & 65 \\
\hline
\end{tabular}

were the primary agents of Prosopis pod disappearance, and prairie dogs were observed utilizing the fleshy carpel and leaving the intact seed on the soil surface. The fate of seeds and pods removed from experimental trays was not determined, but high seedling densities on the North Fork colony (Table 7) suggest that consumption or deep burial (emergence of scarified seeds placed at depths $>5 \mathrm{~cm}$ has been reported at $0 \%$ [Haas et al. 1973]) was either low or exceeded by dispersal of Prosopis seed onto prairie dog colonies. Prosopis large enough to detect on aerial photographs occurred on the Rock Canyon colony prior to prairie dog eradication (Table 8). These plants may have served as the seed source for plants establishing after prairie dog removal (Tables 8-10). However, neither the Santa Rosa nor the North Fork colonies contained plants of seed-producing stature. Where seed-producing Prosopis plants are absent, periodic seed input from offcolony populations would be required if on-colony populations (Table 7) were to persist. Many native herbivores (Coppock et al. 1983b, Whicker and Detling 1988) and livestock (Koford 1958) that preferentially utilize prairie dog colonies may also consume Prosopis pods (Brown and Archer 1987) from trees in off-colony populations and disseminate viable seed onto the colony. Differences in Prosopis seedling and sapling densities between the NF and SR colonies (Table 7) may reflect differences in proximity to off-colony seed sources. Alternatively, maintenance of observed seedling reserves in the absence of seed-producing plants may reflect a residual soil seedbank established during former occupation by Prosopis. P. glandulosa exhibits strong seed-coat dormancy, and seeds can remain viable in soil up to 40-60 yr (Tschirley and Martin 1960). Thus, seeds may persist long after parental plants are gone.

Persistence and development of Prosopis seedlings depends upon abiotic conditions, herbaceous interference, and herbivory. In our study, herbivory was the most important factor influencing survival of Prosopis seedlings during their first year (Fig. 1). Together, prairie dogs and associated fauna reduced on-colony seedling survival by a factor of four. However, a strong interaction between herbaceous interference and susceptibility to herbivory was evident (Fig. 2). Among protected seedlings, survival decreased as herbaceous interference increased. In contrast, survival of nonprotected seedlings increased with increasing herbaceous
TABLE 9. Mean plant density, basal area, total basal area, and relative canopy cover of Prosopis on and off the former Rock Canyon prairie dog colony in 1990.

\begin{tabular}{lrc}
\hline \hline & \multicolumn{2}{c}{ Zone } \\
\cline { 2 - 3 } Parameter & $\begin{array}{c}\text { Former } \\
\text { colony }\end{array}$ & Off-colony \\
\hline Plant density (no./ha) & $2050^{\mathrm{a}}$ & $483^{\mathrm{b}}$ \\
Basal area (cm $/$ plant) & $102^{\mathrm{a}}$ & $342^{\mathrm{b}}$ \\
Basal area (m²/ha) & $21^{\mathrm{a}}$ & $17^{\mathrm{a}}$ \\
Canopy cover (\%) & $64^{\mathrm{a}}$ & $42^{\mathrm{b}}$ \\
Median stem age (yr) & $27^{2}$ & 42 \\
Largest plant age (yr) & 81 & 76 \\
Stems <40 yr old (\%) & 88 & 45 \\
\hline
\end{tabular}

Note: Within a row, means with the same superscript letter were not significantly different $(P>0.05)$. Median stem age, age of largest plant sampled, and proportion of stems initiated since eradication of the prairie dog colony in 1950 were determined using Eq. 1.

interference. Benefits to woody plant seedlings that might otherwise accrue from decreased herbaceous interference caused by defoliation or removal of grasses on the colony appear to have been negated, perhaps by increased apparency or susceptibility to discovery (e.g., Feeny 1976).

When Prosopis seedlings were protected from herbivory, levels of establishment were comparably high $(>75 \%)$ on- and off-colony (Fig. 1), despite substantial differences in herbaceous biomass in these areas (Table 1). This suggests that alterations of vegetation, soils, hydrology, and microclimate by prairie dogs and associated herbivores would not necessarily increase the likelihood of woody plant establishment after prairie dogs vacate a site. Other studies have shown that competition with grasses can significantly reduce woody plant growth rates (Polley et al. 1994, Bush and Van Auken 1995), but this does not necessarily translate into significant reductions in seedling survival (Brown and Archer 1989, O'Connor 1995, Archer 1996). In this study, experimental reductions in herbaceous interference did increase seedling survival, but only slightly (Fig. 2); recruitment was quite high (66\%), even with full interference. The ability of Prosopis to successfully establish and persist in competition with grasses in this northern Texas system has also been demonstrated in grasslands of central and southern Texas (Archer 1996). Thus, in the absence of seedling predation or fire, the probability of Prosopis establishment would be high both on and off prairie dog colonies.

\section{Prosopis persistence on colony sites}

Our field observations of 1-yr-old seedlings and simulated saplings indicated that the majority of stems and leaves on manipulated plants were not consumed. This was consistent with other observations of indiscriminate clipping and felling of vegetation near ground level by prairie dogs (King 1955), an activity thought to facilitate predator detection. The behavior of indiscriminately felling vegetation suggests that our obser- 
TAble 10. Mean density (no./ha) of Prosopis within basal area size classes on and off the former Rock Canyon prairie dog colony in 1990.

\begin{tabular}{crrrrrr}
\hline \hline & \multicolumn{5}{c}{ Plant basal area size class $\left(\mathrm{cm}^{2}\right)$} \\
\cline { 2 - 7 } Zone & $0-100$ & 200 & 300 & 400 & 500 & $>500$ \\
\hline On-colony & $1502^{\mathrm{Aa}}$ & $291^{\mathrm{Aa}}$ & $100^{\mathrm{Ab}}$ & $50^{\mathrm{Ac}}$ & $33^{\mathrm{Ac}}$ & $66^{\mathrm{Abc}}$ \\
Off-colony & $133^{\mathrm{Ba}}$ & $83^{\mathrm{Ba}}$ & $75^{\mathrm{Aab}}$ & $50^{\mathrm{Aab}}$ & $17^{\mathrm{Ab}}$ & $125^{\mathrm{Aa}}$
\end{tabular}

Note: Means within a row with the same lowercase superscript letter and means within a column with the same uppercase superscript letter were not significantly different $(P$ $>0.05)$.

vations of prairie dog "control" of Prosopis may be generally applicable to woody plants. If prairie dogs and associated herbivores do not selectively forage on Prosopis, but rather gnaw stems or defoliate plants after they attain a certain height, seedlings may develop root systems and accumulate enough of a bud bank and nutrient reserve to tolerate intense and repeated defoliation later in their life cycle. Prosopis seedlings are capable of vegetative regeneration within 2 wk of germination (Scifres and Hahn 1971), and 2- and 4-wkold seedlings can withstand repeated shoot removal under controlled environment conditions (Weltzin 1990). This resistance to herbivory may enable Prosopis seedlings to establish and persist on a prairie dog colony for a period of years. The high density of short $(\approx 6 \mathrm{~cm}$ tall) plants on the North Fork Colony (Table 7) may thus represent a vegetative reserve or "seedling bank" (Silvertown 1982, O'Connor 1995). The presence of "seedling" reserves on the Rock Canyon colony site may explain the rapid development of Prosopis stands after the extermination of prairie dogs in 1950 (Tables 8-10). In addition, the removal of prairie dogs may lead to reductions in populations of other herbivores associated with the colony (Fagerstone and Ramey 1996) that are potentially important to Prosopis population regulation (e.g., ants and granivorous deer mice, Peromyscus maniculatus [Uresk 1985]). The dynamics of woody plant stand development following prairie dog removal in other ecosystems may depend on mode of seed dispersal, palatability, forage value, and capacity for vegetative regeneration of the shrub or tree species involved.

\section{Prairie dogs and Prosopis stand development}

The distribution of woody plants across arid and semiarid landscapes is spatially variable, reflecting the effects of topography, geomorphology, and management practices (Tongway and Ludwig 1990, Knight et al. 1994, McAuliffe 1994, Archer 1995). Our results, along with qualitative observations by Osborn (1942) for shinnery oak (Quercus sp.) and sand sagebrush (Artemesia filifolia) scrub savanna in Oklahoma, suggest that historic changes in the distribution and abundance of prairie dogs would have affected spatial and temporal patterns of woody plant development in some landscapes. After prairie dogs were eradicated from the Rock Canyon colony in 1950, Prosopis cover on the former colony site increased rapidly $(1.5 \% / \mathrm{yr})$ relative to other portions of the landscape $(0.8 \% / y r)$ (Table 8$)$. Observed changes in woody plant canopy cover of Prosopis stands in temperate northern Texas are similar to those reported for subtropical southern Texas $(1.0 \% / \mathrm{yr}$ between 1941 and 1983) (Archer et al. 1988) and within the range observed for gallery forest expansion into North American tallgrass prairie (0-3\%/yr; Knight et al. 1994). By 1973, woody plant cover on and off the former Rock Canyon colony was similar. However, differences in Prosopis stand structure reflecting different prairie dog habitation histories were still evident after $40 \mathrm{yr}$ (Tables 9 and 10). Prosopis stands that developed on the former colony were characterized by a high density of small, young plants, whereas the Prosopis stands on non-occupied portions of the landscape were characterized by a lower density of larger, older plants.

\section{Implications for interpreting vegetation patterns}

Numerous examples indicate the importance of herbivory on seedling density and recruitment (McAuliffe 1986, Boyd 1988, Borchert et al. 1989) and plant population, community, and ecosystem dynamics (McNaughton 1983, Naiman 1988, Pastor et al. 1988, Yeaton 1988, Cantor and Whitham 1989, Dublin et al. 1990, Kerbes et al. 1990, Ruess and Halter 1990, Huntly 1991, Stuart-Hill 1992). Removal or exclusion of native herbivores may also produce significant changes in plant communities and ecosystem processes (Sinclair 1979, Watt 1981, Brown and Heske 1990). In some instances, the structure of modern plant assemblages may reflect prehistoric herbivory (Cox 1984, Janzen 1986, Owen-Smith 1987, Blackmore et al. 1990, Noble 1993).

In arid and semiarid regions of western North America, assumptions about the composition and geographic distribution of pre-settlement vegetation are often used, either explicitly or implicitly, as a baseline to assess impacts of land use. Unfortunately, the dearth of information about pre-settlement vegetation constrains our ability to reconstruct effects of land-use activities on vegetation structure. This lack of historical perspective can place short-term studies in the "invisible present" (Magnuson 1990), and can produce misleading conclusions about the causes of present-day patterns and processes. In this study, for example, explanations for differences in stand structure of Prosopis at the Rock Canyon site (Tables 9 and 10) would probably be erroneous without historical knowledge of prairie dog distribution.

Our results suggest that in regions where shrubs or trees such as Prosopis might have been competitive dominants, prairie dogs, when present, would have acted as a keystone species (Paine 1966, Mills et al. 1993) to limit the establishment and dominance of woody vegetation and to maintain a grassland physiognomy. 
The historic physiognomy of communities in arid and semiarid regions may thus have been highly dependent on the former distribution of prairie dogs. Inconsistencies in historical reports of woody plant distribution and abundance in western North America (e.g., abundant by some accounts; absent by others [Malin 1953, Humphrey 1987]) may reflect the fact that (a) prairie dogs occupy selected topoedaphic portions of landscapes; (b) prairie dog colonies may expand rapidly with time (mean annual increases in areal extent up to $200 \%$ ); and (c) disease may periodically reduce prairie dog population density or eliminate entire colonies (Koford 1958, Dahlsted et al. 1981).

Prairie dog colonies occupied some $40 \times 10^{6}$ ha of the Great Plains and Texas in 1919 (Nelson 1919), with individual colonies encompassing up to $64750 \mathrm{~km}^{2}$ (Bailey 1905). Extensive eradication programs initiated in the early 20th century reduced the acreage of prairie dog colonies in the United States by an estimated $98 \%$ (U.S. Department of Interior 1963). Our results suggest that eradication of prairie dogs, in conjunction with reductions in fire frequency (e.g., Madany and West 1983, Savage and Swetnam 1990), released suppressed populations of woody plants such as Prosopis and made large areas available for their colonization. Although changes in climate (Neilson 1986) and atmospheric $\mathrm{CO}_{2}$ concentrations (Idso 1992, Polley et al. 1994) favoring woody plants may have occurred in arid and semiarid regions since settlement, their abundance or stature probably would not increase on landscapes where prairie dogs were present. In contrast, widespread eradication of prairie dogs may have been both necessary and sufficient to enable post-settlement increases in shrublands and woodlands throughout much of western North America. Historical land management designed to remove one perceived impediment to livestock production may therefore have contributed significantly to development of another problem that is now a major impediment to sustainable livestock production.

\section{ACKNOWLEDGMENTS}

This research was the product of discussions with historians and ranchers G. D. and Guy London (born in the early 1900s), who proposed to us that increases in mesquite abundance on their ranch were initiated "after we killed all the prairie dogs." S. Anderson, K. Canon, D. Carlson, J. Cornet, J. A. Cornet, P. Janzen, M. Meixner, and W. Roark assisted with data collection and analysis. We thank them for their help. Special thanks to S. Dowhower for assistance with field work and experimental design. Suggestions of G. Batzli, D. Kaufman, S. Louda, G. McPherson, J. Noble, and N. Seligman on early drafts of the manuscript, and those of two anonymous reviewers on the submitted version of the manuscript, were constructive and helpful. We thank them for their input. Research was supported by Texas Agricultural Experiment Station Project H6717 and USDA/CSRS Grant 89-38300-4508 to S. Archer, the E. Paul and Helen Buck Waggoner Foundation, Incorporated, Vernon, Texas, and by a Texas A\&M/ College of Agriculture Regent's Fellowship to J. F. Weltzin.

\section{Literature Cited}

Agnew, W., D. W. Uresk, and R. M. Hansen. 1986. Flora and fauna associated with prairie dog colonies and adjacent ungrazed mixed-grass prairie in Western South Dakota. Journal of Range Management 39:135-139.

Archer, S. R. 1989. Have South Texas savannas been converted to woodlands in recent history? American Naturalist 134:545-561.

. 1994. Woody plant encroachment into southwestern grasslands and savannas: rates, patterns and proximate causes. Pages 13-68 in M. Vavra, W. A. Laycock, and R. D. Pieper, editors. Ecological implications of livestock herbivory in the West. Society for Range Management, Denver, Colorado, USA.

- 1995. Tree-grass dynamics in a Prosopis-thornscrub savanna parkland: reconstructing the past and predicting the future. Ecoscience 2:83-99.

- 1996. Herbivore mediation of grass-woody plant interactions. Tropical Grasslands 29:218-235.

Archer, S. R., M. G. Garrett, and J. K. Detling. 1987. Rates of vegetation change associated with prairie dog (Cynomys ludovicianus) grazing in North American mixed-grass prairie. Vegetatio 72:159-166.

Archer, S., C. J. Scifres, C. R. Bassham, and R. Maggio. 1988. Autogenic succession in a subtropical savanna: conversion of grassland to thorn woodland. Ecological Monographs 58:111-127.

Bahre, C. J., and M. L. Shelton. 1993. Historic vegetation change, mesquite increases, and climate in southeastern Arizona. Journal of Biogeography 20:489-504.

Bailey, V. 1905. Biological survey of Texas. U.S. Department of Agriculture Biological Survey. North American Fauna 25:9-161.

Bastian, C. T., J. J. Jacobs, and M. A. Smith. 1995. How much sagebrush is too much? An economic threshold analysis. Journal of Range Management 48:73-80.

Belsky, A. J. 1984. Role of small browsing mammals in preventing woodland regeneration in the Serengeti National Park, Tanzania. African Journal of Ecology 22:271-279.

Blackmore, A. C., M. T. Mentis, and R. J. Scholes. 1990. The origin and extent of nutrient-enriched patches within a nutrient-poor savannah in South Africa. Journal of Biogeography 17:463-470.

Borchert, M. I., F. W. Davis, J. Michaelsen, and L. D. Oyler. 1989. Interaction of factors affecting seedling recruitment of blue oak (Quercus douglasii) in California. Ecology 70: 389-404.

Boyd, R. S. 1988. Microdistribution of the beach plant Cakile maritima (Brassicaceae) as influenced by a rodent herbivore. American Journal of Botany 75:1540-1548.

Brown, J. H., and E. J. Heske. 1990. Control of a desertgrassland transition by a keystone rodent guild. Science 250: $1705-1707$.

Brown, J. R., and S. R. Archer. 1987. Woody plant seed dispersal and gap formation in a North American subtropical savanna woodland: the role of domestic herbivores. Vegetatio 73:73-80.

Brown, J. R., and S. R. Archer. 1989. Woody plant invasion of grasslands: establishment of honey mesquite (Prosopis glandulosa var. glandulosa) on sites differing in herbaceous biomass and grazing history. Oecologia 80:19-26.

Buffington, L. C., and C. H. Herbel. 1965. Vegetational changes on a semidesert grassland range. Ecological Monographs 35:139-164.

Bush, J. K., and O. W. Van Auken. 1995. Woody plant growth related to planting time and clipping of a $\mathrm{C}_{4}$ grass. Ecology 76:1603-1609.

Cantor, L. F., and T. G. Whitham. 1989. Importance of belowground herbivory: pocket gophers may limit aspen to rock outcrop refugia. Ecology 70:962-970. 
Chew, R. M. 1976. The impact of small mammals on ecosystem structure and function. Pages 167-180 in D. P. Snyder, editor. Populations of small mammals under natural conditions. Special Publications Series, Number 5. Pymatuning Laboratory of Ecology, University of Pittsburgh, Pittsburgh, Pennsylvania, USA.

Cid, M. S., J. K. Detling, A. D. Whicker, and M. A. Brizuela. 1991. Vegetation responses of a mixed-grass prairie site following exclusion of prairie dogs and bison. Journal of Range Management 44:100-105.

Conover, W. J., and R. L. Iman. 1981. Rank transformations as a bridge between parametric and non-parametric statistics. The American Statistician 35:124-133.

Coppock, D. L., J. K. Detling, J. E. Ellis, and M. I. Dyer. 1983a. Plant-herbivore interactions in a North American mixed-grass prairie. I. Effects of black-tailed prairie dogs on intraseasonal aboveground plant biomass and nutrient dynamics and plant species diversity. Oecologia 56:1-9.

Coppock, D. L., J. E. Ellis, J. K. Detling, and M. I. Dyer. 1983b. Plant-herbivore interactions in a North American mixed-grass prairie. II. Responses of bison to modification of vegetation by prairie dogs. Oecologia 56:10-15.

Cox, G. W. 1984. The distribution and origin of mima mound grasslands in San Diego County, California. Ecology 65: $1397-1405$.

Dahlsted, K. J., S. Sather-Blair, B. K. Worcester, and R. Klukas. 1981. Application of remote sensing to prairie dog management. Journal of Range Management 34:218-223.

Davis, W. B., and D. J. Schmidly. 1994. The mammals of Texas. University of Texas Press, Austin, Texas, USA.

Dublin, H. T., A. R. E. Sinclair, and J. McGlade. 1990. Elephants and fire as causes of multiple stable states in the Serengeti-Mara woodlands. Journal of Animal Ecology 49: $1147-1164$.

El Youssoufi, M. 1992. Factors influencing recruitment of honey mesquite (Prosopis glandulosa var. glandulosa) in a savanna woodland, Texas. Dissertation. Texas A\&M University, College Station, Texas, USA.

Fagerstone, K. A., and C. A. Ramey. 1996. Rodents and lagomorphs. Pages 83-132 in P. R. Krausman, editor Rangeland wildlife. Society for Range Management, Denver, Colorado, USA.

Feeny, P. 1976. Plant apparency and chemical defense. Recent Advances in Phytochemistry 10:1-40.

Flinn, R. C., S. Archer, T. W. Boutton, and T. Harlan. 1994 Identification of annual rings in an arid land woody plant, Prosopis glandulosa. Ecology 75:850-853.

Garrett, M. G., J. L. Hoogland, and W. L. Franklin. 1982. Demographic differences between an old and a new colony of black-tailed prairie dogs (Cynomys ludovicianus). American Midland Naturalist 108:52-59.

Gould, F. W. 1975. Texas plants-a checklist and ecological summary. Texas Agriculture Experiment Station, College Station, Texas, USA.

Grover, H. D., and H. B. Musick. 1990. Shrubland encroachment in southern New Mexico, USA: an analysis of desertification processes in the American southwest. Climatic Change 17:305-330.

Haas, R. H., R. E. Meyer, C. J. Scifres, and J. H. Brock 1973. Growth and development of mesquite. Pages 10-19 in C. J. Scifres, R. W. Bovey, C. E. Fisher, G. O. Hoffman, and R. D. Lewis, editors. Mesquite: growth and development, management, economics, control, uses. Texas Agricultural Experiment Station, College Station, Texas, USA

Hall, E. R. 1981. The mammals of North America. Second edition. John Wiley and Sons, New York, New York, USA

Hastings, J. R., and R. M. Turner. 1965. The changing mile: an ecological study of vegetation change with time in the lower mile of an arid and semi-arid region. University of Arizona Press, Tucson, Arizona, USA.
Heady, H. A. 1975. Rangeland management. McGraw-Hill, New York, New York, USA.

Heitschmidt, R. K., S. L. Dowhower, R. A. Gordon, and D. L. Price. 1985. Response of vegetation to livestock grazing at the Texas Experimental Ranch. Bulletin B-1515. Texas Agricultural Experiment Station, College Station, Texas, USA.

Hennessy, J. T., R. P. Gibbens, J. M. Tromble, and M. Cardenas. 1983. Vegetation changes from 1935 to 1980 in mesquite dunelands and former grasslands of southern New Mexico. Journal of Rangeland Management 36:370-374.

Herbel, C. H., F. N. Ares, and R. A. Wright. 1972. Drought effects on a semidesert grassland range. Ecology 53:10841093.

Hibbard, K. A. 1995. Landscape patterns of carbon and nitrogen dynamics in a subtropical savanna: observations and models. Dissertation. Texas A\&M University, College Station, Texas, USA.

Hicks, C. R. 1973. Fundamental concepts in the design of experiments. Holt, Rinehart, and Winston, New York, New York, USA.

Humphrey, R. R. 1987. 90 years and 535 miles: vegetation changes along the Mexican border. University of New Mexico Press, Albuquerque, New Mexico, USA.

Huntly, N. 1991. Herbivores and the dynamics of communities and ecosystems. Annual Review of Ecology and Systematics 22:477-503.

Idso, S. B. 1992. Shrubland expansion in the American southwest. Climate Change 22:85-86.

Inglis, J. M. 1964. A history of vegetation on the Rio Grande Plains. Texas Parks and Wildlife Department, Austin, Texas, USA.

Janzen, D. H. 1986. Chihuahuan Desert nopaleras: defaunated big mammal vegetation. Annual Review of Ecology and Systematics 17:595-636.

Johnson, H. B., H. W. Polley, and H. S. Mayeux. 1993. Increasing $\mathrm{CO}_{2}$ and plant-plant interactions: effects on natural vegetation. Vegetatio 104-105:157-170.

Johnston, M. C. 1963. Past and present grassland of southern Texas and northeastern Mexico. Ecology 44:456-466.

Jones, C. G., J. H. Lawton, and M. Shachak. 1994. Organisms as ecosystem engineers. Oikos 69:373-386.

Kerbes, R. H., P. M. Kotanen, and R. L. Jefferies. 1990. Destruction of wetland habitats by lesser snow geese: a keystone species on the west coast of Hudson Bay. Journal of Applied Ecology 27:242-258.

King, J. A. 1955. Social behavior, social organization, and population dynamics in a black-tailed prairie dog town in the Black Hills of South Dakota. Contributions from the Laboratory of Vertebrate Biology Number 67. University of Michigan, Ann Arbor, Michigan, USA.

Koford, C. B. 1958. Prairie dogs, whitefaces, and blue grama. Wildlife Monographs 3:6-78.

Knight, C. L., J. M. Briggs, and M. D. Nelis. 1994. Expansion of gallery forest on Konza Prairie Research Natural Area, Kansas, USA. Landscape Ecology 9:117-125.

Louda, S. M. 1989. Differential predation pressure: a general mechanism for structuring plant communities along complex environmental gradients? Trends in Ecology and Evolution 4:158-159.

MacLeod, N. D. 1993. Economic cost of shrub encroachment in Western New South Wales. Pages 58-63 in E. L. Delfosse, editor. Pests of pastures. CSIRO, Melbourne, Australia.

Madany, M. H., and N. E. West. 1983. Livestock grazingfire regime interactions within montane forests of Zion National Park, Utah. Ecology 64:661-667.

Magnuson, J. J. 1990. Long-term ecological research and the invisible present. BioScience 40:495-501.

Malin, J. C. 1953. Soil, animal and plant relations of the 
grasslands historically recorded. Scientific Monthly 76: 207-220.

McArthur, E. D. 1984. Natural diversity of western range shrubs. Pages 193-209 in J. L. Cooley and J. H. Cooley, editors. Natural diversity in forest ecosystems. Institute of Ecology, Athens, Georgia, USA.

McAuliffe, J. R. 1986. Herbivore-limited establishment of a Sonoran Desert tree, Cercidium microphyllum. Ecology 67:276-280.

. 1994. Landscape evolution, soil formation, and ecological patterns and processes in Sonoran Desert bajadas. Ecological Monographs 64:111-148.

McKell, C. M. 1989. The biology and utilization of shrubs. Academic Press, San Diego, California, USA.

McNaughton, S. J. 1983. Serengeti grassland ecology: the role of composite environmental factors and contingency in community organization. Ecological Monographs 53: 291-320.

Mills, L. S., M. E. Soulé, and D. F. Doak. 1993. The keystone species concept in ecology and conservation. BioScience 43:219-224.

Naiman, R. J. 1988. Animal influences on ecosystem dynamics. BioScience 38:750-752.

Neilson, R. P. 1986. High resolution climatic analysis and southwest biogeography. Science 232:27-34.

Nelson, E. W. 1919. Annual report of Chief of Bureau of Biological Survey. Pages 257-275 in Annual reports of the Department of Agriculture for the year ended June 30, 1918. U.S. Government Printing Office, Washington, D.C., USA.

Noble, J. C. 1993. Relict surface-soil features in semi-arid Mulga (Acacia aneura) woodlands. Rangeland Journal 15 : $48-70$.

O'Connor, T. G. 1995. Acacia karoo invasion of grassland: environmental and biotic effects influencing seedling emergence and establishment. Oecologia 103:214-223.

Osborn, B. 1942. Prairie dogs in shinnery (oak scrub) savannah. Ecology 23:110-115.

Owen-Smith, N. 1987. Pleistocene extinctions: the pivotal role of megaherbivores. Paleobiology 13:351-362.

Paine, R. T. 1966. Food web complexity and species diversity. American Naturalist 100:65-75.

Pastor, J., R. J. Naiman, B. Dewey, and P. McInnes. 1988 Moose, microbes, and the boreal forest. BioScience $\mathbf{3 8}$ $770-775$.

Polley, H. W., H. B. Johnson, and H. S. Mayeux. 1994. Increasing $\mathrm{CO}_{2}$ : comparative responses of the $\mathrm{C}_{4}$ grass $\mathrm{Schi}$ zachyrium and grassland invader Prosopis. Ecology 75: 976-988.

Ruess, R. W., and F. L. Halter. 1990. The impact of large herbivores on the Serona Woodlands, Serengeti Nationa Park, Tanzania. African Journal of Ecology 28:259-275.

SAS Institute. 1988. SAS/STAT user's guide, release 6.03 edition. SAS Institute, Cary, North Carolina, USA.

Savage, M., and T. W. Swetnam. 1990. Early 19th-century fire decline following sheep pasturing in a Navajo ponderosa pine forest. Ecology 71:2374-2378.

Schlesinger, W. H., J. F. Reynolds, G. L. Cunningham, L. F Huenneke, W. M. Jarrell, R. A. Virginia, and W. G. Whitford. 1990. Biological feedbacks in global desertification. Science 247:1043-1048

Schofield, C. J., and E. H. Bücher. 1986. Industrial contributions to desertification in South America. Trends in Ecology and Evolution 1:78-80.
Scifres, C. J. 1980. Brush management. Texas A\&M University Press, College Station, Texas, USA.

Scifres, C. J., and R. R. Hahn. 1971. Response of honey mesquite seedlings to top removal. Journal of Range Management 24:396-398.

Silvertown, J. W. 1982. Introduction to plant population ecology. Longman, New York, New York, USA.

Simpson, B. B., editor. 1977. Mesquite: its biology in two desert scrub ecosystems. US/IBP Synthesis Series 4. Halstead, New York, New York, USA.

Sinclair, A. R. E. 1979. Dynamics of the Serengeti ecosystem. Pages 1-30 in A. R. E. Sinclair and M. Norton-Griffiths, editors. Serengeti: dynamics of an ecosystem. University of Chicago Press, Chicago, Illinois, USA.

Skarpe, C. 1991. Impact of grazing in savanna ecosystems. Ambio 20:351-356.

Smith, J. R., and J. M. Beverly. 1981. The use and analysis of staggered nested factorial designs. Journal of Quality Technology 13:166-173.

Soil Conservation Service. 1959. Soil survey of Wilbarger County, Texas, USA. USDA Series 1959, Number 18.

Steel, R. G. D., and J. H. Torrie. 1980. Principles and procedures of statistics: a biometrical approach. Second edition. McGraw-Hill, New York, New York, USA.

Stuart-Hill, G. C. 1992. Effects of elephants and goats on the Kaffrarian succulent thicket of the eastern Cape, South Africa. Journal of Applied Ecology 29:699-710.

Tongway, D. J., and J. A. Ludwig. 1990. Vegetation and soil patterning in semi-arid mulga lands of Eastern Australia. Australian Journal of Ecology 15:23-34.

Tschirley, F. H., and S. C. Martin. 1960. Germination and longevity of velvet mesquite seed in soil. Journal of Range Management 13:94-97.

Turner, R. M. 1990. Long-term vegetation change at a full protected Sonoran Desert site. Ecology 71:464-477.

Uresk, D. W. 1985. Effects of controlling black-tailed prairie dogs on plant production. Journal of Range Management 38:466-468.

U.S. Department of Interior. 1963. Inventory of areas occupied by prairie dogs in 1961. Circular Letter, Branch of Predator and Rodent Control. U.S. Fish and Wildlife Service, Washington, D.C., USA.

Walker, B. H. 1993. Stability in rangelands: ecology and economics. Pages 1885-1890 in M. J. Baker, J. R. Crush, and L. R. Humphreys, editors. XVII International Grassland Congress. Keeling and Monday, New Zealand/Australia.

Watt, A. S. 1981. A comparison of grazed and ungrazed grassland A in East Anglian Breckland. Journal of Ecology 69:499-508.

Weltzin, J. F. 1990. The potential role of prairie dogs in regulating honey mesquite population dynamics. Thesis. Texas A\&M University, College Station, Texas, USA.

Westoby, M., B. Walker, and I. Noy-Meir. 1989. Opportunistic management for rangelands not at equilibrium. Journal of Range Management 42:266-274.

Whicker, A. D., and J. K. Detling. 1988. Ecological consequences of prairie dog disturbances. BioScience 38:778785.

Yeaton, R. I. 1988. Porcupines, fires and the dynamics of the tree layer of the Burkea africana savanna. Journal of Ecology 76:1017-1029.

Young, M. D., and O. T. Solbrig. 1993. The world's savannas: economic driving forces, ecological constraints and policy options for sustainable land use. Parthenon, Carnforth, UK. 